\title{
Constituents and Anthelmintic Activity Evaluation of Albizia Adiantifolia (Schumach) W.F. Wright Essential Oils FromNigeria
}

\author{
Akinsola Akande ${ }^{1}$, Sherifat Aboaba ${ }^{1}$, Guido Flamini ${ }^{2}$ \\ ${ }^{1}$ Department of Chemistry, University of Ibadan, Ibadan, Nigeria \\ ${ }^{2}$ Dipartimento di Farmacia, Universita di Pisa, Pisa, Italy \\ Correspondence: Sherifat Aboaba, Department of Chemistry, University of Ibadan, Ibadan, Nigeria. \\ E-mail: saboaba@gmail.com
}

Received: December 27, 2017 Accepted: March 4, 2018 Online Published: March 30, 2018

doi:10.5539/ijc.v10n2p10

URL: https://doi.org/10.5539/ijc.v10n2p10

\begin{abstract}
Albizia adiantifolia (Schumach) W.F. Wright (Fabaceae) is a plant used traditionally in treating different health ailments which includes worm infections. The essential oils (EOs) were obtained by hydrodistillation in an all glass Clevenger apparatus, and characterized by gas chromatography (GC) and gas chromatography-mass spectrometry analysis (GC-MS). In vitro petri-dish anthelmintic activity was carried out using adult earthworm, Eudrilus eugeniae. The leaves, stem bark and root bark EOs afforded a total of 40, 26 and 20 constituents representing 90.9\%, 94.1\% and 90.9\% of the total oil fractions respectively. The classes of compounds identified in the leaves, stem bark and root bark are oxygenated monoterpenes $(4.1 \%, 1.7 \%$ and $4.0 \%$ respectively), sesquiterpene hydrocarbons $(39.5 \%, 67.3 \%$ and $42.6 \%$ respectively), oxygenated sesquiterpenes $(18.7 \%, 22.3 \%$ and $30.1 \%$ respectively), non-terpene derivatives $(12.1 \%$, $2.6 \%$ and $14.2 \%$ respectively) and apocarotenoids (16.5\% and $0.2 \%$ in the leaves and stem-bark). $\beta$-caryophyllene (23.0\%), E-geranylacetone (7.4\%), acorenone (6.4\%), viridiflorol (6.4\%), $\alpha$-zingiberene (6.3\%) and ar-curcumene $(4.6 \%)$ were the major constituents in the leaves oil, $\beta$-caryophyllene (39.3\%), selin-11-en-4- $\alpha$-ol (10.4\%), $\alpha$-zingiberene $(9.6 \%)$, ar-curcumene $(7.2 \%)$, caryophyllene oxide $(6.4 \%)$ and $\alpha$-humulene $(5.6 \%)$ were the major constituents in the stem bark oil, while $\beta$-caryophyllene $(32.1 \%)$, selin-11-en-4- $\alpha$-ol $(13.1 \%)$, caryophyllene oxide (8.4\%), pentadecanal (6.1\%) and $\alpha$-humulene (4.4\%) were the major constituents in the root bark oil. $\beta$-caryophyllene dominated the oils. The leaf EO was the most active against E. eugeniae worm. All the oils showed a relatively higher activity compared to Albendazole, in a concentration dependent manner. There was significant difference $(\mathrm{p}<0.001)$ in activity.
\end{abstract}

Keywords: Albizia adiantifolia, Clevenger apparatus, $\beta$-caryophyllene, Eudrilus eugeniae, Albendazole

\section{Introduction}

Albizia adiantifolia (Schumach) W.F. Wight is a large deciduous tree commonly known as "the West African Albizia or rough-bark flat-crown" in English (Orwa et al., 2009) and locally referred to as Ayinreta, igbabo (Yoruba) and kawo (Hausa) in Nigeria (Lawal et al., 2010). A. adiantifolia is a tree in the Fabaceae family distributed majorly from Senegal, Kenya, Angola, South Africa, Swaziland and extending to Eastern Madagascar. Domestically it has found use as firewood, furniture, as well as in vehicle body, cabinet works, and locally valued as a shade tree for some crops such as cocoa and coffee. It can also be used for soil improvement and conservation while the gum from the bark is used in cosmetics (Lemmens, 2007). In traditional medicine, various parts are used in treating different ailments such as toothache, bronchitis, diarrhea, tapeworm infection (anthelmintic), abdominal pains, typhoid fever, urinary and respiratory tracts infections, Alzheimer's disease and as an antidote against poison. It is also used as vermifuge, purgative, irregular menstruation and even administered to women in child labour (Orwa et al., 2009, Lawal et al., 2010, Lemmens, 2007, Tamokou et al., 2012, Beppe et al., 2014, Abubakar and Majinda, 2015). A. adiantifolia administered alone or in combination with Trichilia dregeana Sond., can be used to treat Gonorrhea and Syphilis (De Wet et al., 2012).

Extracts from different parts of the plant possess activities such as antioxidant (Tamokou et al., 2012 and Beppe et al., 2014) anxiety, depression and oxidative stress activities (Beppeet al., 2015) antimicrobial, haemolytic, in vitro immunomodulatory, anti-inflammatory and anticholinesterase activities (Tamokou et al., 2012 and Abubakar and Majinda, 2015). Lupeol, aurantiamide, D-pinitol, protocatechuic acid as well as triterpenoidal saponins and several flavonoids which are reported to be contained in different parts, have been isolated from the plant (Tamokou et al., 2012 and Abubakar and Majinda, 2015). 
The objective of this study is to extract and characterize the essential oils (EOs) from A. adiantifolia leaves, stem bark and root bark, and further determine their in vitro anthelmintic activity using Eudrilus eugeniae adult earthworm.

\section{Materials and Methods}

\subsection{Sample Collection and Essential Oil Isolation}

Samples from the leaves, stem bark and root bark of the plant were collected fresh from a forest vegetation at Awotan area in Ibadan, Oyo state, Nigeria in July 2013 and identified at the herbarium of Forest Research Institute of Nigeria (FRIN), Jericho Ibadan where voucher specimens were deposited with herbarium number FHI 109922. Pulverized leaves (300 g), stem bark (350 g) and root back (350 g) samples were used in an all-glass Clevenger apparatus designed according to British Pharmacopoeia specifications (MHRA, 1980) to obtain the essential oils by hydrodistillation method in 4 hours. The oils were dried over anhydrous sodium sulphate $\left(\mathrm{Na}_{2} \mathrm{SO}_{4}\right)$ and stored inside the refrigerator at $4^{\circ} \mathrm{C}$ prior to use.

\subsection{Gas Chromatography - Mass Spectrometry (GC-MS) Analysis}

Gas Chromatographic (GC) analyses of the essential oils were performed on a HP-5890 Gas chromatograph equipped with a HP-Wax and HP-5 capillary columns $(30 \mathrm{~m} \times 0.25 \mathrm{~mm}$, film thickness of $0.25 \mathrm{~mm}$ ). The GC oven temperature which was programmed at $60{ }^{\circ} \mathrm{C}$ was held for $10 \mathrm{~min}$ and heated to $220^{\circ} \mathrm{C}$ at $5{ }^{\circ} \mathrm{C} / \mathrm{min}$. The temperature for both the injector and the detector was maintained at $250{ }^{\circ} \mathrm{C}$. The carrier gas used was Helium at a flow rate of $2 \mathrm{~mL} / \mathrm{min}$. The Gas Chromatographic-Mass Spectrometry (GC-MS) analyses were carried out on a Varian CP-3800 gas chromatograph interfaced to a Varian Saturn 2000 ion trap Mass Detector operated at $70 \mathrm{eV}$. The injector and transfer line temperatures were $220^{\circ} \mathrm{C}$ and $240{ }^{\circ} \mathrm{C}$, respectively. The $\mathrm{GC}$ oven temperature was programmed from $60{ }^{\circ} \mathrm{C}$ to $240{ }^{\circ} \mathrm{C}$ at $3{ }^{\circ} \mathrm{C} / \mathrm{min}$. Helium was used as a carrier gas at a flow rate of $1 \mathrm{~mL} / \mathrm{min}$. The constituents of the oils were identified on the basis of comparison of the retention times with those of the authentic samples, comparing their retention indices relative to the series of n-hydrocarbons, and by comparison of their mass spectra with published spectra and those of reference compounds from NIST, 2002. The relative concentration of each constituent was calculated by integration of GC peak areas (Adams, 2007).

\subsection{Anthelmintic Assay}

Preliminary evaluation of in vitro anthelmintic activity was carried out according to the method by Priya et al., 2012 with slight modifications. Indigenous in Africa, the adult earthworm (Eudrilus engeniae) commonly known as the West African night crawler (Monebi and Ugwumba, 2013, Obohet al., 2007 and Dominguez et al., 2001) was used owing to its anatomical and physiological resemblance with the intestinal roundworm parasites of human beings (Lakshananam et al., 2011, Thomas and Devi, 2013 and Pueblos et al., 2015). These adult earthworms are common species in our region of study. Average sizes of the earthworms, $6-8 \mathrm{~cm}$ in length and $0.2-0.3 \mathrm{~cm}$ in width, were collected from moist soils and identified in the department of Zoology, University of Ibadan, Ibadan. They were washed with distilled water to remove any faecal matter.Albendazole, (ALBZ) (brand name - ZENTEL, by ${ }^{\circ}$ SmithKline Beecham Lab. Pharm.), often extensively administered clinically as an anthelmintic drug, was the test standard. EOs are relatively insoluble in water but were made soluble in Tween-80 (10\% v/v in distilled water). The EOs and ALBZ were dissolved in $10 \mathrm{~mL}$ Tween-80 and diluted up to $30 \mathrm{~mL}$ to prepare five concentrations $(1,2,3,4$ and $5 \% \mathrm{v} / \mathrm{v}$ for each of $\mathrm{EO}$ and ALBZ) in five petri-dishes. Five worms each were introduced into each concentration. 10\% v/v Tween- 80 in distilled water was used as negative control. Observations were made to determine the time for paralysis (when no movement could be observed except when shaken vigorously) and death (when worms neither wriggled when shaken nor moved when pinched with a needle, followed with fading away of body colour) of worms to have taken place. Activity was achieved by comparing results obtained for the EO extracts with that of the reference standard drug Albendazole.

Values for time of paralysis and death were expressed as mean \pm standard error of mean (SEM). Analysis of variance (ANOVA), followed by student's t test was carried out using Graph Pad Prism, version 5.01 statistical software to determine the significance of differences between experimental and control groups. At $95 \%$ confidence interval, $p$ values $<0.001$ were considered statistically significant.

\section{Results and Discussion}

The hydrodistilled leaves, stem bark and root bark essential oils (EOs) of Albizia adiantifolia obtained by Gas Chromatography (GC) and Gas Chromatography-Mass Spectrometry (GC-MS) analyses yielded $0.26 \%, 0.23 \%$ and $0.25 \%(\mathrm{v} / \mathrm{w})$ respectively. As presented in table 1, a total of 40,26 and 20 constituents representing $90.9 \%, 94.1 \%$ and $90.9 \%$ of the total oil fractions in the leaves, stem bark and root bark were identified. Based on the class of compounds present, complex mixtures in the leaves, stem-bark and root-bark were identified, such as oxygenated monoterpenes (4.1\%, $1.7 \%$ and $4.0 \%$ respectively), sesquiterpene hydrocarbons - the most dominant class $(39.5 \%, 67.3 \%$ and $42.6 \%$ respectively), oxygenated sesquiterpenes $(18.7 \%, 22.3 \%$ and $30.1 \%$ respectively), non-terpene derivatives $(12.1 \%$, $2.6 \%$ and $14.2 \%$ respectively) and apocarotenoids $(67.3 \%$ and $42.6 \%)$ in the leaves and stem-bark. Interestingly, none of the constituents present are in the class of monoterpene hydrocarbons. 
The leaves essential oil constitutes majorly $\beta$-caryophyllene (23.0\%), E-geranylacetone (7.4\%), acorenone (6.4\%), viridiflorol $(6.4 \%), \alpha$-zingiberene $(6.3 \%)$ and ar-curcumene $(4.6 \%)$, while the stem bark oil is dominated by $\beta$-caryophyllene (39.3\%), selin-11-en-4- $\alpha$-ol (10.4\%), -zingiberene (9.6\%), ar-curcumene (7.2\%), caryophyllene oxide $(6.4 \%)$ and -humulene (5.6\%). Also, the root bark oil contained majorly $\beta$-caryophyllene (32.1\%), selin-11-en-4- $\alpha$-ol (13.1\%), caryophyllene oxide $(8.4 \%)$, pentadecanal $(6.1 \%)$ and $\alpha$-humulene $(4.4 \%)$. In the pattern of oil composition, -zingiberene and $a r$-curcumene were the dominant compounds in the leaves and stem bark, while selin-11-en-4- $\alpha$-ol, caryophyllene oxide and $\alpha$-humulene altogether dominated the stem bark and root bark oils. $\beta$-caryophyllene is the most abundant constituent in the three EOs. Other significant constituents include 1,8 -cineole $(2.2 \%, 1.5 \%, 1.9 \%$ in the leaves, stem bark and root bark respectively), $\beta$-sesquiphellandrene $(2.5 \%$ and $2.8 \%$ in the leaves and stem bark respectively), valerianol ( $2.9 \%$ in the root bark) and $\delta$-cadinene (3.8\% in the root bark).

$\beta$-caryophyllene, the dominant constituent of Commiphora gileadensis EO (which is also one of the major oil constituents identified in this study), possesses many pharmacological properties such as anti-inflammatory, antifungal, local anesthetic and has been reported that the EO exhibited antiproliferative pro-apoptotic effects in tumor cells (Eitan et al., 2012). Also, it was identified as a dominant component of Garcinia mangostana Linn. leaves and stem bark EOs. G. mangostana oils exhibited high toxicity $\left(\mathrm{LC}_{50}\right.$ values of 1.70 and $5.15 \mu \mathrm{g} / \mathrm{mL}$, leaves and stem bark respectively) against brine shrimp (Artemia salina) and also showed antibacterial activities against some clinical isolates (Aboaba et al., 2014). Furthermore, $\beta$-caryophyllene and $\beta$-caryophyllene oxide are documented to occur in a large number of plants and possess significant anticancer activities by affecting growth and proliferation of numerous cancer cells (Fidyt et al., 2016).

Murraya paniculata (L.) Jack, is a traditional medicinal plant for the treatment of abdominal pain, diarrhea, stomach ache, headache, edema, thrombosis, and blood stasis. Three of the major constituents ( $\beta$-caryophyllene, $\alpha$-zingiberene and selin-6-en-4-ol) identified in the EOs of M. Paniculata leaves are similar to the major constituents found in this study. The oil was reported to show moderate activity in the brine shrimp lethality test $\left(\mathrm{LC}_{50}=41 \mu \mathrm{g} / \mathrm{mL}\right)$ and a high nematicidal activity against Caenorhabditi selegans $\left(\mathrm{LC}_{50}=37 \mu \mathrm{g} / \mathrm{mL}\right)$ (Dosoky et al., 2016). Eugenol and $\beta$-caryophyllene dominated Ocimum sanctum Linn. In addition, the essential oil showed potent in vitro anthelmintic activity against the nematode $C$. elegans according to Mali and Mehta, 2008. Zingiberene is the dominant constituent of ginger. As a medicine, ginger essential oil and its oleoresin are used to aid digestion, as an expectorant and as a cure for stomach ache, toothache, diarrhea and asthmatic respiratory disorders (Kamaliroosta et al., 2013). Zingiberene has also been suggested as an important ingredient in stomachic medications (Malhotra and Singh 2003).

The result in table 2 shows the anthelmintic activity of $A$. adiantifolia essential oils. It was observed that the time of paralysis and death of worms decreases as concentration increases. The leaf essential oil shows activity higher than both the stem bark and root bark oils with time of paralysis and death at 12.60 and 60.20 minutes, respectively for the highest concentration. At all concentrations, the essential oils were more active than the standard drug (Albendazole) used. The effect of varying the concentrations of $A$. adiantifolia essential oils and albendazole were significantly different from one another. All values were also significantly different from the reference standard $(\mathrm{p}<0.001)$.

Many of the in vitro investigations on anthelmintic efficacy of plant extracts and their essential oils have been based on the effects they pose on organisms such as earthworms (Sutar et al., 2010; Akhtar et al., 2000; Bairagi et al., 2011; Mali and Mehta, 2008) as well as various gastro-intestinal nematodes (roundworms), cestodes (tapeworms) and trematodes (flukes) of human and livestock (Akhtar et al., 2000; Mali and Mehta, 2008; Ferreira et al., 2013). Due to the availability and easy access to earthworms, suitable models for anthelmintic drug screening have been established (Subash et al., 2012; Mali and Mehta, 2008). Many substances toxic to earthworms tend to cause irritation which eventually often lead to withdrawal of the worm from the environment of such substance, or cause flaccid paralysis. However, by virtue of these effects, very probably, anthelmintics would act by a way of expelling parasitic worms from their host's gastrointestinal tract through peristalsis (Subash et al., 2012; Akhtar et al., 2000).

\section{Conclusions}

The compositional patterns and components of $A$. adiantifolia essential oils of Nigeria origin are reported for the first time. Sesquiterpene hydrocarbons dominated the leaves, stem bark and root bark essential oils. Result from the anthelmintic assay displayed the activity of $A$. adiantifolia oils against the worm used and their potency were inversely proportional to the time taken for paralysis and death of the worms to occur. The three essential oils show a relatively higher activity compared to Albendazole in concentration dependent manner which could be attributed to one or more components of the oil. This result could be a preliminary inference to the traditional medicinal usage of the plant in treating tapeworm infection, abdominal pains and as purgative. Also, owing to known activities demonstrated by some of the compounds identified in the oils, further suggests the potential pharmacological activities of the plant. Since the discovery and treatment of diseases with herbs has been on the increase, and the attention which their active principles have attracted as sources for new drugs, A. adiantifolia essential oils could be a good natural product for many pharmacological activities. 
Table 1. Essential oil constituents of A. adiantifolia from GC/GC-MS analysis

\begin{tabular}{|c|c|c|c|c|c|}
\hline Constituents & L.R.I & L.R.I ${ }^{*}$ & AAL & AASB & AARB \\
\hline 2-heptanone ${ }^{f}$ & 891 & 889 & 0.8 & - & - \\
\hline Benzaldehyde $^{\mathrm{f}}$ & 962 & 952 & - & - & 1.4 \\
\hline 1-octen-3-one ${ }^{f}$ & 980 & 972 & - & - & 0.9 \\
\hline 6-methyl-5-hepten-2-one ${ }^{\mathrm{f}}$ & 987 & 981 & 1.0 & - & - \\
\hline 2-octanone ${ }^{\mathrm{f}}$ & 993 & 988 & 1.0 & - & - \\
\hline Mesitylene $\mathrm{f}^{\mathrm{f}}$ & 996 & 994 & - & - & 1.4 \\
\hline 1,8 -cineole $\mathrm{f}$ & 1034 & 1026 & 2.2 & 1.5 & 1.9 \\
\hline Seudenone ${ }^{f}$ & 1063 & - & 0.4 & - & - \\
\hline Linalool $^{\mathrm{b}}$ & 1101 & 1095 & 0.8 & - & 2.1 \\
\hline Nonanal $^{f}$ & 1104 & 1100 & 1.6 & - & - \\
\hline 2,4-dimethylbenzaldehyde $\mathrm{f}^{\mathrm{f}}$ & 1179 & - & 0.4 & - & - \\
\hline Naphthalene ${ }^{\mathrm{f}}$ & 1181 & 1178 & 0.6 & - & 1.1 \\
\hline$(Z, E)$-undeca-1,3,5-triene ${ }^{\mathrm{f}}$ & 1182 & - & 0.5 & - & - \\
\hline$\alpha$-terpineol ${ }^{\mathrm{b}}$ & 1191 & 1186 & 0.4 & - & - \\
\hline Safranal $^{\mathrm{e}}$ & 1197 & 1196 & 0.7 & - & - \\
\hline Decanal $^{\mathrm{f}}$ & 1206 & 1201 & 0.4 & - & - \\
\hline$\beta$-cyclocitral ${ }^{\mathrm{e}}$ & 1222 & 1217 & 1.4 & - & - \\
\hline$p$-menth-4-en-3-one ${ }^{\mathrm{b}}$ & 1251 & - & 0.7 & - & - \\
\hline$\beta$-cyclohomocitral ${ }^{\mathrm{e}}$ & 1256 & - & 0.7 & - & - \\
\hline 5-methyltetralin ${ }^{\mathrm{f}}$ & 1264 & - & 0.5 & - & - \\
\hline Thymol $^{\mathrm{b}}$ & 1292 & 1289 & - & 0.2 & - \\
\hline$n$-tridecane $\mathrm{f}^{\mathrm{f}}$ & 1300 & 1300 & 0.5 & - & - \\
\hline$\alpha$-ionone ${ }^{\mathrm{f}}$ & 1352 & - & 0.6 & - & - \\
\hline Dehydro- $a r$-ionene ${ }^{\mathrm{f}}$ & 1353 & - & 0.5 & - & - \\
\hline$(E)-\beta$-damascenone ${ }^{\mathrm{e}}$ & 1382 & 1383 & 0.7 & - & - \\
\hline 1,4-dimethyltetralin ${ }^{\mathrm{f}}$ & 1391 & - & 0.5 & - & - \\
\hline$\beta$-elemene $e^{c}$ & 1392 & 1389 & - & 0.5 & - \\
\hline Cyperene $^{c}$ & 1398 & 1398 & - & - & 2.3 \\
\hline$n$-tetradecane ${ }^{\mathrm{f}}$ & 1400 & 1400 & 1.3 & - & - \\
\hline Isocaryophyllene $^{\mathrm{c}}$ & 1405 & 1408 & - & 0.4 & - \\
\hline Italicene $^{\mathrm{c}}$ & 1405 & 1405 & 0.7 & - & - \\
\hline$\beta$-caryophyllene ${ }^{c}$ & 1419 & 1417 & 23.0 & 39.3 & 32.1 \\
\hline$(E)$ - $\alpha$-ionone ${ }^{\mathrm{e}}$ & 1428 & 1428 & 0.5 & 0.2 & - \\
\hline cis- $\alpha$-ambrinol $^{\mathrm{e}}$ & 1437 & 1439 & 0.4 & - & - \\
\hline 2-phenylethyl butanoate ${ }^{f}$ & 1440 & 1439 & - & - & 0.9 \\
\hline$\alpha$-humulene $\mathrm{e}^{\mathrm{c}}$ & 1455 & 1452 & 2.4 & 5.6 & 4.4 \\
\hline$(E)$-geranyl acetone ${ }^{\mathrm{e}}$ & 1457 & 1453 & 7.4 & - & - \\
\hline Sesquisabinene ${ }^{c}$ & 1460 & 1457 & - & 0.8 & - \\
\hline$\gamma$-muurolene ${ }^{c}$ & 1478 & 1478 & - & 0.3 & - \\
\hline$a r$-curcumene ${ }^{\mathrm{c}}$ & 1483 & 1479 & 4.6 & 7.2 & - \\
\hline$(E)-\beta$-ionone ${ }^{\mathrm{e}}$ & 1487 & 1487 & 4.7 & - & - \\
\hline$\alpha$-zingiberene ${ }^{c}$ & 1496 & 1493 & 6.3 & 9.6 & - \\
\hline$\alpha$-bulnesene $\mathrm{e}^{\mathrm{c}}$ & 1507 & 1509 & - & 0.2 & - \\
\hline$\beta$-bisabolene $\mathrm{c}^{\mathrm{C}}$ & 1508 & 1505 & - & 0.3 & - \\
\hline trans- $\gamma$-cadinene $^{\mathrm{c}}$ & 1514 & 1513 & - & 0.3 & - \\
\hline$\delta$-cadinene ${ }^{\mathrm{c}}$ & 1524 & 1522 & - & - & 3.8 \\
\hline$\beta$-sesquiphellandrene ${ }^{c}$ & 1525 & 1521 & 2.5 & 2.8 & - \\
\hline Occidentalol $^{\mathrm{d}}$ & 1548 & 1550 & - & - & 1.7 \\
\hline$(E)$-nerolidol ${ }^{\mathrm{d}}$ & 1564 & 1561 & 0.7 & 0.5 & - \\
\hline Caryophyllene oxide ${ }^{d}$ & 1582 & 1582 & 3.6 & 6.4 & 8.4 \\
\hline Viridiflorol $^{\mathrm{d}}$ & 1591 & 1592 & 6.4 & 2.7 & 3.0 \\
\hline trans- $-\beta$-elemenone $^{\mathrm{d}}$ & 1601 & 1601 & - & 0.3 & - \\
\hline Humulene epoxide II ${ }^{\mathrm{d}}$ & 1607 & 1608 & - & 0.5 & 1.0 \\
\hline Tetradecanal $^{\mathrm{f}}$ & 1614 & 1611 & - & 0.8 & 1.0 \\
\hline Caryophylla-4(14),8(15)-dien-5-ol ${ }^{\mathrm{d}}$ & 1636 & 1639 & 0.8 & 0.8 & - \\
\hline T-cadinol $^{\mathrm{d}}$ & 1641 & 1638 & 0.8 & 0.5 & - \\
\hline Selin-11-en-4- $\alpha-$ ol $^{\mathrm{d}}$ & 1655 & 1658 & - & 10.4 & 13.1 \\
\hline Valerianol $^{\mathrm{d}}$ & 1656 & 1656 & - & - & 2.9 \\
\hline Acorenone $^{\mathrm{d}}$ & 1688 & 1692 & 6.4 & 0.2 & - \\
\hline 2-pentadecanone ${ }^{\mathrm{f}}$ & 1699 & 1697 & - & - & 1.4 \\
\hline Pentadecanal $^{\mathrm{f}}$ & 1716 & - & 1.5 & 1.8 & 6.1 \\
\hline${ }^{\mathrm{a}}$ Monoterpene hydrocarbons & & & 0.0 & 0.0 & 0.0 \\
\hline${ }^{\text {bOxygenatedmonoterpenes }}$ & & & 4.1 & 1.7 & 4.0 \\
\hline 'Sesquiterpene hydrocarbons & & & 39.5 & 67.3 & 42.6 \\
\hline${ }^{\mathrm{d}}$ Oxygenatedsesquiterpenes & & & 18.7 & 22.3 & 30.1 \\
\hline 'Apocarotenoids & & & 16.5 & 0.2 & 0.0 \\
\hline${ }^{f}$ Non-terpene derivatives & & & 12.1 & 2.6 & 14.2 \\
\hline Total identified & & & 90.9 & 94.1 & 90.9 \\
\hline
\end{tabular}

Major constituents are represented in bold

$\mathrm{LRI}=$ Linear retention index; $\mathrm{LRI}^{*}=$ Linear retention index values from Adams, 2007; $\mathrm{AAL}=$ Albizia adiantifolia leaves; $\mathrm{AASB}=$ Albizia adiantifolia stem bark; $\mathrm{AARB}=$ Albizia adiantifolia root bark. 
Table 2. Anthelmintic activity of Albizia adiantifolia essential oils

\begin{tabular}{|c|c|c|c|c|}
\hline \multirow[b]{2}{*}{$\begin{array}{c}\text { EO Conc. } \\
(\% \mathrm{v} / \mathrm{v})\end{array}$} & \multicolumn{4}{|c|}{ Time of Paralysis (Mins) expressed as Mean \pm SEM $(\mathrm{N}=5)$} \\
\hline & AAL & AASB & AARB & ALBZ \\
\hline 1.00 & $30.40 \pm 1.36$ & $32.80 \pm 2.01$ & $34.00 \pm 1.64$ & $97.20 \pm 1.39$ \\
\hline 2.00 & $25.80 \pm 1.71$ & $27.20 \pm 1.43$ & $28.60 \pm 1.60$ & $94.20 \pm 1.77$ \\
\hline 3.00 & $20.20 \pm 1.28$ & $24.40 \pm 1.50$ & $24.80 \pm 1.71$ & $89.60 \pm 1.29$ \\
\hline 4.00 & $17.00 \pm 1.73$ & $18.20 \pm 1.28$ & $20.00 \pm 1.22$ & $87.40 \pm 1.08$ \\
\hline \multirow[t]{2}{*}{5.00} & $12.60 \pm 1.21$ & $15.60 \pm 0.93$ & $16.60 \pm 1.08$ & $82.80 \pm 1.28$ \\
\hline & \multicolumn{4}{|c|}{ Time of Death (Mins) expressed as Mean \pm SEM (N=5) } \\
\hline $\begin{array}{l}\text { EO Conc. } \\
(\% \mathrm{v} / \mathrm{v})\end{array}$ & AAL & AASB & AARB & ALBZ \\
\hline 1.00 & $96.20 \pm 3.51$ & $98.20 \pm 3.22$ & $101.40 \pm 3.97$ & $154.60 \pm 1.86$ \\
\hline 2.00 & $85.60 \pm 2.66$ & $89.80 \pm 2.87$ & $98.00 \pm 3.18$ & $149.20 \pm 2.35$ \\
\hline 3.00 & $78.60 \pm 2.54$ & $80.80 \pm 2.60$ & $87.40 \pm 3.36$ & $140.60 \pm 1.72$ \\
\hline 4.00 & $70.40 \pm 3.43$ & $72.80 \pm 2.96$ & $76.80 \pm 2.65$ & $135.00 \pm 1.92$ \\
\hline $\mathbf{5 . 0 0}$ & $60.20 \pm 3.09$ & $61.20 \pm 2.73$ & $69.60 \pm 2.94$ & $130.20 \pm 1.77$ \\
\hline
\end{tabular}

$\mathrm{AAL}=$ Albizia adiantifolia leaves; $\mathrm{AASB}=$ Albizia adiantifolia stem bark; AARB = Albizia adiantifolia root bark; ALBZ $=$ Albendazole (Standard); SEM $=$ Standard error of mean; $\mathrm{N}=$ number of worms in each petri-dish.

The time taken for paralysis and death of worms to occur in distilled water (negative control) was observed to be $>>200$ minutes. This is due to the body cells eventually absorbing water by osmosis.

\section{Acknowledgements}

The authors are grateful to Mr. Adedapo Adeniran of the Department of Pharmacognosy, Faculty of Pharmacy, University of Ibadan, for putting us through the anthelminthic assay.

\section{References}

Aboaba, S., Akande, A., \& Flamini, G. (2014). Chemical composition, toxicity and antibacterial activity of the essential oils of Garcinia mangostana from Nigeria. Journal of Essential Oil Bearing Plants, 17(1), 78-86. https://doi.org/10.1080/0972060X.2014.884759

Abubakar, M. N., \& Majinda, R. R. T. (2015). Phytochemical constituents and antimicrobial activity of Albizia Adianthifolia. JPRPC, 3(4), 46-51.

Adams, R. (2007). Identification of Essential Oil Components by Gas Chromatography/Mass spectrometry. 4th ed. Allured Publishing Corporation, Carol Stream IL, USA.

Akhtara, M. S., Iqbal, Z., Khan, M. N., \& Lateef, H. (2000). Anthelmintic activity of medicinal plants with particular reference to their use in animals in the Indo-Pakistan subcontinent. Small Ruminant Research, 38, 99-107. https://doi.org/10.1016/S0921-4488(00)00163-2

Bairagi, G. B., Kabra, A. O., \& Mandade, R. J. (2011). Anthelmintic activity of Citrus medica L. leaves in Indian adult earthworm. International Journal of Pharm Tech Research, 3(2), 664-667.

Beppe, G. J., Dongmo, A. B., Foyet, H. S., Dimo, T., Mihasan, M., \& Hritcu, L. (2015). The aqueous extract of Albizia adianthifolia leaves attenuates 6-hydroxydopamine induced anxiety, depression and oxidative stress in rat amygdale. BMC Complementary and Alternative Medicine, 15, 374.https://doi.org/10.1186/s12906-015-0912-0

Beppe, G. J., Dongmo, A. B., Foyet, H. S., Tsabang, N., Olteanu, Z., Cioanca, O., ... Hritcu, L. (2014). Memory-enhancing activities of the aqueous extract of Albizia adianthifolia leaves in the 6-hydroxydopamine lesion rodent model of Parkinson's disease. BMC Complementary and Alternative Medicine, 14, 142. https://doi.org/10.1186/1472-6882-14-142

De Wet, H., Nzama, V. N., \& Van Vuuren, S. F. (2012). Medicinal plants used for the treatment of sexually transmitted infections by lay people in northern Maputa land, KwaZulu-Natal Province, South Africa. South African Journal of Botany, 78, 12-20. https://doi.org/10.1016/j.sajb.2011.04.002

Dominguez, J., Edwards, C. A., \& Ashby, J. (2001). The biology and population dynamics of Eudrilus eugeniae (Kinberg) (Oligochaeta) in cattle waste solids. Pedobiologia, 45, 341-353. https://doi.org/10.1078/0031-4056-00091

Dosoky, N. S., Satyal, P., Gautam, T. P., \& Setzer, W. N. (2016). Composition and biological activities of Murraya paniculata (L.) Jack essential oil from Nepal. Medicines, 3(7), 1-10. https://doi.org/10.3390/medicines3010007

Eitan, A., Rivka, O., Nativ, D., Elaine, S., Tatiana, R., \& Shimon, R. (2012). $\beta$-caryophyllene, a compound isolated from the Biblical balm of Gilead (Commiphora gileadensis), is a selective apoptosis inducer for tumor cell-lines. Evidence-based complementary and alternative medicine. Article ID 872394. 8. 
Ferreira, L. E., Castro, P. M. N., Chagas, A. C. S., França, S. C., \& Beleboni, R. O. (2013). In vitro anthelmintic activity of aqueous leaf extracts of Annona muricata L. (Annonaceae) against Haemonchus contortus from sheep. Experimental Parasitology, 134, 327-332. https://doi.org/10.1016/j.exppara.2013.03.032

Fidyt, K., Fiedorowicz, A., Strządała, L., \& Szumny, A. (2016). $\beta$-caryophyllene and $\beta$-caryophyllene oxide - natural compounds of anticancer and analgesic properties. Cancer Med., 5(10), 3007-3017. https://doi.org/10.1002/cam4.816

Kamaliroosta, Z., Kamaliroosta, L., \& Elhamirad, A. H. (2013). Isolation and identification of ginger essential oil. Journal of Food Biosciences and Technology, 3, 73-80.

Lakshananam, B., Mazumber, M. P., Sasmal, D., Ganguly, S., \& Jena, S. S. (2011). In vitro anthelmintic activity of some 1-substituted imidazole derivatives. ActaParasitol.Globalis, 2(1), 1-5.

Lawal, I. O., Uzokwe, N. E., Igboanugo, A. B. I., Adio, A. F., Awosan, E. A., Nwogwugwu, J. O., \& Adesoga, A. A. (2010). Ethno-medicinal information on collation and identification of some medicinal plants in research institutes of South-west Nigeria. Afr. J. Pharm. Pharmacol., 4, 1-7.

Lemmens, R. H. M. J. (2007). Albizia adianthifolia (Schumach.)W.Wight. [Internet] Record from PROTA4U.Louppe, D., Oteng-Amoako, A.A. and Brink, M. (Editors). PROTA (Plant Resources of Tropical Africa/Ressourcesvégétales de l'Afriquetropicale), Wageningen, Netherlands.<http://www.prota4u.org/search.asp>. Accessed 28 February 2015.

Malhotra, S., \& Singh, A. P. (2003). Medicinal properties of Ginger (Zingiber officinale). Natural product radiance, 2(6), 296-301.

Mali, R. G., \& Mehta, A. A. (2008). A review on anthelmintic plants. Natural Product Radiance, 7(5), 466-475.

Medicines and Healthcare products Regulatory Agency (MHRA) (1980). British Pharmacopoeia, Vol. II; H.M. Stationery Office, Pharmaceutical Press: London, UK.

Monebi, C. O., \& Ugwumba, A. A. A. (2013). Utilization of the earthworm, Eudrilus engeniae in the diet of Heteroclarias fingerlings. International Journal of Fisheries and Aquaculture, 5(2), 19-25.

Oboh, B. O., Akintobi, D. O., \& Ejidereonwu, C. (2007). Morphometric studies in Eudrilus eugeniae populations from different locations in Lagos, Nigeria. Nature and Science, 5(2), 16-21.

Orwa, C., Mutua, A., Kindt, R., Jamnadas, R., \& Anthony, S. (2009). Albizia adianthifolia (Schumach.) W. Wight. Agroforestree Database: a tree reference and selection guide version 4.0. http://www.worldagroforestry.org/sites/treedbs/treedatabases.asp. 5

Priya, S. R., Sheth, N. R., \& Jayaveera, K. N. (2012). Anthelmintic activity of essential oil of Pimentadioica (Linn.) Merill, Family: Myrtaceae, collected in Summer from South Canara, India. Euro. J. Exp. Bio., 2(6), 2271-2275.

Pueblos, K. R. S., Lagare, J. P. B., Tapales, P. V. P. P., \& Quimque, M. T. J. (2015). In vitro anthelmintic activity evaluation of the aerial part of Ruellia tuberose Linn.against Eudrilus eugeniae. International Symposium on Applied Chemistry. Procedia Chemistry, 16, 570-577. https://doi.org/10.1016/j.proche.2015.12.094

Subash, K. R., Rao, N. J., Cheriyan, B. V., Bhaarati, G. M., \& Kumar, K. S. (2012). Anthelmintic activity of Eupatorium triplinerve and Alpiniagalanga in Pheritima posthuma and Ascardia galli. Journal of Clinical and Diagnostic Research, 6(6), 947-950.

Sutar, N., Garai, R., Sharma, U. S., Sharma, U. K., \& Jaiswal, A. (2010). Anthelmintic activity of Platycladus orientalis leaves extract. International Journal of Parasitology Research, 2(2), 1-3. https://doi.org/10.9735/0975-3702.2.2.1-3

Tamokou, J. D., Mpetga, D. J. S., Lunga, P. K., Tene, M., Tane, P., \& Kuiate, J. R. (2012). Antioxidant and antimicrobial activities of ethyl acetate extract, fractions and compounds from stem bark of Albizia adianthifolia (Mimosoideae). BMC Complement Altern Med., 12, 99. https://doi.org/10.1186/1472-6882-12-99

Thomas, S., \& Devi, B. S. (2013). Phytochemical and in vitro anthelmintic studies of hydro-alcoholic extract of Costus pictus D. Don. Int. J. Pharm. Sci., 5(3), 639-641.

\section{Copyrights}

Copyright for this article is retained by the author(s), with first publication rights granted to the journal.

This is an open-access article distributed under the terms and conditions of the Creative Commons Attribution license (http://creativecommons.org/licenses/by/4.0/). 